\title{
Challenges in Pretreatment/Treatment of Oil in Water Emulsions for Oil Waste Management in the Context of Sustainable Development
}

\author{
GEORGETA MADALINA ARAMA ${ }^{1}$, LIDIA KIM ${ }^{1 *}$, DIANA STROIA ${ }^{2}$ \\ ${ }^{1}$ National Research and Development Institute for Industrial Ecology ECOIND Bucharest, 71-73 Drumul Podul \\ Dambovitei Str., 060652, Bucharest, Romania \\ ${ }^{2}$ SC SETCAR SA, 6 Gradinii Publice Str., 810022, Braila, Romania
}

\begin{abstract}
The purpose of the article is to present practical, technical and ecological challenges in the pretreatment/treatment technologies of spent oil waste that are oil-in-water emulsion systems containing high volumes of water difficult to be temporary stored. A set of experimental tests on representative oil-in-water spent emulsions have been realized based on a set of treatment screening criteria so that any oil-waste producer/holder can use them to find best pretreatment solutions preventing on-site oil waste generation and preserving in the same time depletion of non-renewable natural resources by recovery of valuable components in the context of sustainable development.
\end{abstract}

Keywords: emulsions, oil-in water emulsions, waste oils

\section{Introduction}

In the present paper we are focusing on oil/waste containing spent emulsions of oil-in-water type named also "soluble oils" made of mineral oil, additives (emulsifiers, corrosion inhibitors, antifoaming agents) and water coming from a large class of products used in metal surface processing as lubrication and cooling agents [1]. Basel Convention defines as used oil, liquid or semi-solid products being made totally or partially of 1) mineral oils or synthetic hydrocarbons, 2) oil residues from the oil storage tanks and 3) mixtures of water-oil including the emulsionated ones that are coming from a large range of applications from different industries [2]. Their mismanagement, i.e. their inappropriate discharge in the sewage systems and other places can induce serious negative impacts to environment and human health. The efforts made for their correct evaluation and characterization [3-8] leading to their recovery - reuse, recycling or incineration - can bring important economic, ecologic and social benefits [9]. Waste oils recovery [10] is recognized as especially appropriate for the implementation of circular economy concept [11], intensely promoted in latest years within EU countries and adopted worldwide as a sustainable development strategic approach. This aiming for the creation of close economic models able to minimize the environmental negative impacts generated along the life cycle of the product/service and if it is possible even to bring them to "zero", transforming waste from one industry in raw materials for another [12 - 13]. Although circular economy is not an easy to implement concept [14 - 15] systematic efforts have been made in Europe for its implementation. In this context, in order to help achieving good management practices, EU Directive 2008/98/CE [16] requires for all hazardous waste including waste oils to be collected separately where this is technically feasible and not hamper their subsequent pretreatment/treatment. The challenges in finding best waste oil pretreatment/treatment technologies for recovery purposes are linked to the large amounts of water and a high variety of additives they contain. The water makes "soluble oils" more susceptible to rust problems, bacterial growth, evaporation losses that is precisely why a variety of different additives are added to control such problems and to increase their useful life [9]. In this respect, a set of technical screening criteria for finding on-site best oil waste pretreatment/ treatment technologies should represent a useful management tool for each oil waste producer/holder

$\overline{\text { *email: lidia.kim@incdecoind.ro }}$ 
because an increasing use of those additives is reflected in modified characteristics of oil-in-water emulsions. These modified characteristics lead to the "need for selecting a combination of different separation technologies that fulfill stringent legislation norms for reuse of water and also other valuable components" [17] as we will show in this paper.

\section{Materials and methods}

To fulfill our proposed objective, we performed a set of demonstrative experimental tests with two sample types (S1 and S2) representing spent cutting oil fluids that generally are classified under the code $120109^{*}$ - machining emulsions and solutions free of halogens. The two primary functionalities of spent cutting oil fluids are lubrication and cooling. They are generally made of: mineral oils (naphthenic or paraffinic), emulsifiers (one or more emulsifiers generally mono-and poly-alkyl amines), anticorrosive agents (glycol or fatty acids). The description and content of the wastes are given in Table 1.

Table 1. Description and content of the waste

\begin{tabular}{|c|c|c|}
\hline Sample Type & Description & Content \\
\hline S1 & $\begin{array}{l}\text { - liquid with milky aspect and a } \mathrm{pH}: 9.5 \div 10.0 \\
\text { - left without shaking at the room temperature after } \\
\text { one week tends to separate an oil phase with a } \\
\text { volume up to } 1 \% \text { of the initial sample volume } \\
\text { without sedimented solids. }\end{array}$ & $\begin{array}{c}\text {-mineral oil (petroleum distillates-hydro treated heavy } \\
\text { paraffinic components); } \\
\text {-additives (mono-ethanol-amines; } \\
\text {-R-tert-alkyl amines; } \\
\text {-tert-alkanolamines; } \\
\text {-ethoxylated amines; } \\
\text {-morpholine derivatives; } \\
\text {-sodium sulphonates; } \\
\text {-ethoxylated polymer; } \\
\text {-3 iodoprop-2 yn-1-yl butyl carbamate } \\
\text {-polyglycol; } \\
\text {-5-chloro-2-methyl-4-isothiazolin-3-one }\end{array}$ \\
\hline S2 & $\begin{array}{l}\text { - liquid with brown dark color, boiling point of } \\
\qquad 100^{\circ} \mathrm{C} \text { and } \mathrm{pH} 7 \div 8 \text {; } \\
\text { - left without shaking at the room temperature after } \\
\text { one week has no tendency to separate an oil phase } \\
\text { or solid sediments }\end{array}$ & $\begin{array}{c}\text {-hydro treated naphthenic distillates (petroleum); } \\
\text {-hydroxyl ethyl oleamides; } \\
\text {-sulphonic acid sodium salts; } \\
\text {-amino-ethanol; } \\
\text {-2-(2-butoxyethoxy) ethanol; }\end{array}$ \\
\hline
\end{tabular}

For a successful on-spot general pretreatment of oily waste for phases separation, it is advisable that any waste oil producer/holder consider some important aspects/criteria before a pretreatment plan should to be set: I) visual aspect (color transparency); II) tendency to separate in gravitational field when left without heating and without shaking and the presence of sediments; III) $\mathrm{pH}$ waste; IV) composition from specifications of concentrated "soluble oil" used to prepare the oil in water emulsions that become actually components of the oil waste. To demonstrate how to use these criteria we realized experimental tests presented in Table 2, for the two above-mentioned sample types S1 and S2.

Table 2. Experimental tests conditions

\begin{tabular}{|c|c|c|}
\hline Sample & & Experimental tests \\
\hline \multirow{4}{*}{ S1 } & Test A & temperature modification $\left(50 \div 60^{\circ} \mathrm{C}\right)$ coupled with settling for 2,4 , and $24 \mathrm{~h}$ \\
\hline & Test $B$ & $\mathrm{pH}$ modification $\left(\mathrm{pH}_{\mathrm{i}}: 9.0 \div 10.5\right.$ towards final $\left.\mathrm{pH}_{\mathrm{f}}: 3 \div 4\right)$ coupled with settling for 2,4 , and $24 \mathrm{~h}$ \\
\hline & Test $C$ & temperature and $\mathrm{pH}$ modifications coupled with settling for $2,4,24 \mathrm{~h}$ \\
\hline & Test $D$ & temperature and $\mathrm{pH}$ modifications with progressive centrifugation for $10 \mathrm{~min}$ followed by settling for $2,4,24 \mathrm{~h}$ \\
\hline S2 & Test $E$ & ecular weight substances \\
\hline
\end{tabular}

The relevant investigated indicators for the water and oil phases and the analytical used methods for their determination are given in Table 3. 
Table 3. Investigated indicators and analytical methods-equipment

\begin{tabular}{cc}
\hline Indicators & Analytical methods-equipment \\
\hline Water phase & \\
\hline TH & SR EN ISO 10523:2012 - pH-meter MULTI 9430-WTW \\
\hline Petroleum Products (PP) & SR EN ISO 7072:2001 - SPECORD 2015 - Analytic Jena \\
\hline Chemical Oxygen Demand (COD) & SR ISO 6060:1996 - Volumetric Method \\
\hline Dissolved Organic Carbon (DOC) & SR7877/1-95; IR SR 7877-2:1995 - FT-IR Spectrum BX Perkin Elmer \\
\hline Oil phase & SR EN 1484 :2006 - Analyzer DOC Analytic Jena Multi N/C 3100 \\
\hline Water content & ASTM D240:17 - Parr 6200 Calorimeter Off Systems \\
\hline Superior Calorific Power $\left(\mathrm{Q}_{\mathrm{s}}\right)$ & ASTM D 240:17; PIS 35 by computation \\
\hline Inferior Calorific Power $\left(\mathrm{Q}_{\mathrm{i}}\right)$ & ASTM D 5291:16 - Elemental Analyzer FLASH EA 112 Pro Analysis \\
\hline Carbon $(\mathrm{C})$ & ASTM D 5291:16 - Elemental Analyzer FLASH EA 112 Pro Analysis \\
\hline Hydrogen $(\mathrm{H})$ & ASTM D 5291:16 - Elemental Analyzer FLASH EA 112 Pro Analysis
\end{tabular}

\section{Results and discussions}

According to the presented criteria, we have tried to use the simplest ways to test how to increase phase separation for the sample $\mathrm{S} 1$ and $\mathrm{S} 2$. The results are presented and discussed next.

Test A - sample S1 - temperature modification (heating) and 2, 4, $24 \mathrm{~h}$ settling - Heating is known to produce a reduction of viscosity of the oil phase, increasing the mobility and promoting coalescence of particles, and phase separation can be improved if coupled with 2, 4, $24 \mathrm{~h}$ settling. However, progressive heating up to $50 \div 60^{\circ} \mathrm{C}$ showed irrelevant changes in destroying stability of the tested sample 1 system even if it was coupled with 2, 4, $24 \mathrm{~h}$ settling process.

Test B - sample $\mathrm{S} 1$ - $p \mathrm{H}$ modification and 2, 4, $24 \mathrm{~h}$ settling - Progressive change of initial $\mathrm{pH}$ from $p \mathrm{H}_{\mathrm{i}}: 9.0 \div 10.5$ towards final $\mathrm{pH}_{\mathrm{f}}: 3 \div 4$ have been performed in order to note changes in the range of intermediate $p \mathrm{H} 5 \div 8$. In extreme $p \mathrm{H}$ range less than 4 the emulsions regain stability. Although creaming process occurred, the lower layer is still emulsionated enough (still milky). The optimum $p \mathrm{H}$ ranges to destroy stability should not go under $\mathrm{pH} 4$ and not over 5 with small variations depending on specific composition of the corresponding used sample.

Test $\mathrm{C}$ - sample $\mathrm{S} 1$ - progressive heating coupled with $p \mathrm{H}$ changes and settling for 2,4 , and 24 hours. Going with $p \mathrm{H}$ about 4 we have tried to see if we can obtain a better value for the COD indicator (Chemical Oxygen Demand) - removal of organic substances from the system and to note the importance of hydration/dehydration process of different ions in the system with different radii using only concentrated acids $\left(\mathrm{H}_{2} \mathrm{SO} 4, \mathrm{H}_{3} \mathrm{PO} 4, \mathrm{HCl}\right)$. Only the water and oil phases separated after $24 \mathrm{~h}$ have been analyzed. Results are presented in Table 4 . The efficiency has been computed as $100 \mathrm{x}$ $\left(\mathrm{C}_{\mathrm{i}}-\mathrm{C}_{\mathrm{f}} / \mathrm{C}_{\mathrm{i}}\right)$ where $\mathrm{C}_{\mathrm{i}}$ is the initial started concentration and $\mathrm{C}_{\mathrm{f}}$ is the final concentration.

For the recovered water phase obtained as a result of test $\mathrm{C}$ the abatement efficiencies for the relevant investigated indicators were: in the range of $99.2 \div 99.9 \%$ for turbidity and petroleum products and about $90 \%$ for COD and DOC.

For the recovered oil phase obtained as a result of test $\mathrm{C}$, the values of the investigated relevant indicators were pretty close to the characteristics of a diesel type fuel which makes this technological approach suitable for further optimization.

Table 4. Results for the recovered water and oil phase - Test C

\begin{tabular}{|c|c|c|c|c|c|c|}
\hline \multirow{3}{*}{$\begin{array}{l}\text { Water Phase Sample Name: } \\
\text { W1 } \\
\text { (from sample type S1) }\end{array}$} & \multicolumn{6}{|c|}{ Recovered water phase indicators from Test $\mathrm{C}$} \\
\hline & \multirow[t]{2}{*}{$\mathbf{p H}_{\mathbf{i}}$} & \multirow[t]{2}{*}{$\mathrm{pH}_{\mathrm{f}}$} & Turbidity & COD & DOC & $\mathbf{P P}$ \\
\hline & & & NTU & $\mathrm{mg} / \mathrm{L}$ & $\mathbf{m g} / \mathbf{L}$ & $\mathrm{mg} / \mathrm{L}$ \\
\hline $\mathbf{W 1} 1_{0}$ (initial sample S1) & $9 \div 10$ & $9 \div 10$ & 242100 & 311040 & 86700 & 73253 \\
\hline W1 H2SO4 t, s (heated sample type S1 - treated & $9 \div 10$ & $3 \div 4$ & 224 & 34992 & 8320 & 28 \\
\hline
\end{tabular}


with $\mathrm{H} 2 \mathrm{SO} 4$ conc. followed by settling)

\begin{tabular}{|c|c|c|c|c|c|c|}
\hline Efficiency (\%) & - & - & 99.91 & $\underline{88.75}$ & $\underline{90.40}$ & 99.96 \\
\hline $\begin{array}{l}\text { W1 } 1 \text { H3PO4 t, s (heated sample type S1 - treated } \\
\text { with H3PO4 conc. followed by settling) }\end{array}$ & $9 \div 10$ & $3 \div 4$ & 213 & 50058 & 8970 & 339 \\
\hline Efficiency (\%) & & & 99.91 & $\underline{83.91}$ & $\underline{89.65}$ & $\underline{99.53}$ \\
\hline $\begin{array}{l}\text { W1 } 1_{\text {HCL } t \text {, s (heated sample type S1 - treated }} \\
\text { with HCl conc. followed by settling) }\end{array}$ & $9 \div 10$ & $3 \div 4$ & 1784 & 30132 & 7685 & 250 \\
\hline Efficiency (\%) & & & 99.26 & $\underline{90.31}$ & 91.14 & $\underline{99.65}$ \\
\hline
\end{tabular}

Oil Phase Sample Name O1

(from sample type S1)

O1t, s (combined oil phases separated by settling from the three above-mentioned - treatments heated sample type $S 1$ - treated with conc. acids followed by settling )
Recovered oil phase indicators from Test $\mathrm{C}$

$\begin{array}{llllll}\mathbf{Q}_{s} & \mathbf{Q}_{\mathrm{i}} & \text { Total } & \mathbf{C}_{\text {total }} & \mathbf{H}_{\text {total }} & \mathbf{N}_{\text {total }}\end{array}$

Humidity

\begin{tabular}{cccccc}
\hline Kcal/Kg & Kcal/Kg & $\%$ & $\%$ & $\%$ & $\%$ \\
\hline$\underline{8312}$ & $\underline{7656}$ & $\underline{21.26}$ & $\underline{70.83}$ & $\underline{12.95}$ & $\underline{0.56}$
\end{tabular}

Test D - sample type S1 - progressive heating coupled with $\mathrm{pH}$ changes and progressive centrifugation for $10 \mathrm{~min}$ at $6000 \mathrm{rpm}$ followed by settling for 2, 4, and $24 \mathrm{~h}$ in order to note changes. Using a centrifugation process we have tried to show that with the usual capabilities of an industrial centrifuge used in the oil field for example the results that are presented in Table 5 are pretty similar for water phase indicators to those obtained following a simple settling process presented in Table 4 but not for oil phase which have a much higher water content.

Table 5. Results for the recovered water and oil phase - Test D

Water Phase Sample Name: W2 Recovered water phase indicators from Test D

(from sample type S1)

$\begin{array}{llllll}\mathrm{pH}_{\mathrm{i}} & \mathrm{pH}_{\mathrm{f}} & \text { Turbidity } & \text { COD } & \text { DOC } & \text { PP }\end{array}$

\begin{tabular}{|c|c|c|c|c|c|c|}
\hline & & & & & & \\
\hline & & & $N T U$ & $m g / L$ & $m g / l$ & $m g / L$ \\
\hline $\mathbf{W} \mathbf{2}_{0}$ (initial sample S1) & $9 \div 10$ & $9 \div 10$ & 242100 & 311040 & 86700 & 73253 \\
\hline $\begin{array}{l}\text { W2 } 2 \text { H2SO4 t,c (heated sample type S1 - treated with } \\
\text { H2SO4 conc. followed by centrifugation.) }\end{array}$ & $9 \div 10$ & $3 \div 4$ & 121 & 38800 & 8250 & 28 \\
\hline Efficiency (\%) & - & - & 99.95 & 87.52 & 90.48 & $\underline{99.96}$ \\
\hline  & $9 \div 10$ & $3 \div 4$ & 196 & 39852 & 9020 & 34 \\
\hline Efficiency (\%) & & & 99.91 & $\underline{87.19}$ & $\underline{89.60}$ & $\underline{99.95}$ \\
\hline $\begin{array}{l}\text { W2 } 2_{\text {HCL t,c (heated sample type S1 - treated with HCl }} \\
\text { conc. followed by centrifugation ) }\end{array}$ & $9 \div 10$ & $3 \div 4$ & 1203 & 34020 & 7962 & 600 \\
\hline Efficiency (\%) & & & 99.50 & $\underline{89.06}$ & $\underline{90.82}$ & $\underline{99.18}$ \\
\hline
\end{tabular}




\begin{tabular}{|c|c|c|c|c|c|c|}
\hline $\begin{array}{l}\text { Oil Phase Sample Name: } \mathrm{O2} \\
\text { (from sample type S1) }\end{array}$ & \multicolumn{6}{|c|}{ Humidity } \\
\hline O2 t.c (combined oil phases separated by settling from & Kcal/Kg & Kcal/Kg & $\%$ & $\%$ & $\%$ & $\%$ \\
\hline $\begin{array}{l}\text { the three above-mentioned treatments - heated sample type } \\
\text { S1 - treated with conc. acids followed by centrifugation) }\end{array}$ & $\underline{3318}$ & 2975 & $\underline{49.62}$ & $\underline{36.44}$ & $\underline{8.75}$ & $\underline{0.55}$ \\
\hline
\end{tabular}

With the presented pretreatment approaches we concluded that a balance should be made between obtained efficiencies of separation and costs of heating, reagents and certain type of equipment in order to find optimum costs of pretreatment. In this respect we can make some useful practical remarks from the technical point of view. In the case of those emulsions types, efficiency of phases separation will increase each time we will increase a residence time of settling, decrease the $p \mathrm{H}$ (see good results from tests $\mathrm{A}, \mathrm{B}, \mathrm{C}$, and $\mathrm{D}$ with optimum $p \mathrm{H}$ being in the range of $4 \div 5$ ) and increase temperature (heating), the latest option being obviously more expensive. Any other option without heating that gives results in the same range should be considered in balance with generated costs. For example, the obtained efficiencies after $p \mathrm{H}$ adjustment, heating, and $24 \mathrm{~h}$ settling time and after $\mathrm{pH}$ adjustment, heating, and 10 min centrifugation are in the same range (see results from Table 4 and Table 5) for water phase but not for oil phase. In this example the investigation of using a more expensive equipment (an industrial centrifuge) should be justified only when large volumes of emulsions should to be treated in order to speed up the process. For small volumes to be treated a usual settling equipment will be always preferred to a more expensive centrifugation equipment. For the sample type S2 we have tried to demonstrate how criteria IV - composition - can orient about finding optimum pretreatment/treatment solutions and we realized test $\mathrm{E}$ (Table 2). In this test, for phases separation we used small and high molecular weight compounds to produce aggregation through mainly cationic species in the range of almost neutral $p \mathrm{H}$ decreasing in the same time the time oh operation. Initial sample type S2 (Figure $1 \mathrm{a}$ )) contains about $11.79 \%$ of water with a carbon content of $80.01 \%$ having a superior calorific power Qs of $8739 \mathrm{kcal} / \mathrm{kg}$. The initial sample type $\mathrm{S} 2$ has been treated with small


macromolecular cationic type of polyelectrolyte - sol. $0.2 \% 25 \div 50 \mathrm{ppm}$, used mainly as flocculant [18 - 19] reaching a final $p \mathrm{H}$ of 5.5-6.0. The presented test $\mathrm{E}$ is a pretreatment/preliminary test. Our intention was just to have a rough orientation about the treatment that should be followed and optimized, therefore the presented obtained results should be regarded only as a rough guidance for future technological optimization. For this preliminary test E, we used a medium charged cationic type polymer because this type of polymer has well known particles aggregation capabilities in the chosen treatment $p \mathrm{H}$ range and for the sample type $\mathrm{S} 2$ with composition presented in Table 1 . The formed floccons characteristics are facilitating both rapid sedimentation and phases separation leading to a clear supernatant and afterwards to a clear filtrate. Good and rapid cake filterability was also obtained for the separated solid phase. In Figure 1 a), b), c), d) are presented the visual modifications of the sample $\mathrm{S} 2$ in the proposed pretreatment method marking the emulsion destabilization.

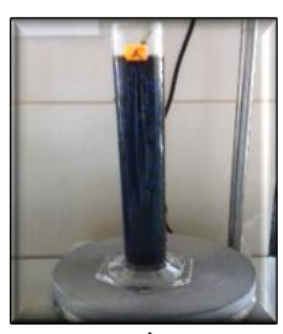

a)

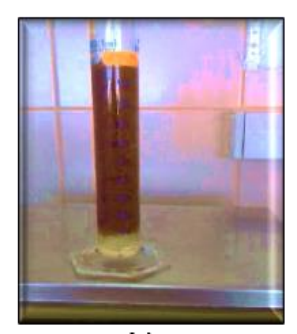

b)

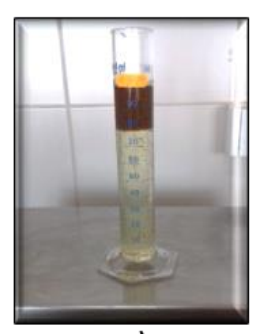

c)

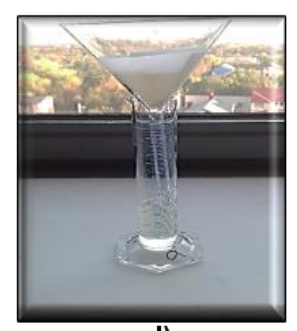

d)

Figure 1. The sample $S 2$ aspect in the phase separation process

a) initial sample; b) coagulated sample; c) sample after 1hour settling; 
d) sample filtrated after has been coagulated and left 1 hour for settling

The system changed the color from brown dark to reddish brown and phase separation was immediately (Figure $1 \mathrm{~b}$ )). The creaming process after one hour is presented in Figure $1 \mathrm{c}$ ). A superior reddish brown layer representing about $20 \%$ in volumes of the initial treated sample was separated. The sample was filtered through a filter paper retaining $2 \div 3$ microns. The filtration process was rapid $100 \mathrm{~mL}$ in $10 \mathrm{~min}$ and the turbidity for the filtrate reached $6 \mathrm{NTU}$ and a COD of approximatively 2200 $\mathrm{mg} / \mathrm{L}$ (Figure $1 \mathrm{~d}$ )). As reference a potable water should have a turbidity $<5 \mathrm{NTU}$ and the quality of water that can be discharged into a surface water should have a COD of $500 \mathrm{mg} / \mathrm{L}$ according to Romanian laws [20]. Those techniques supported by good analytical monitoring practices and increased waste management efforts can help protect the environment from pollution [21-24].

\section{Conclusions}

The purpose of our paper was to offer a set of technical screening criteria I-IV that should be considered when setting on-site pretreatment methods. They are a useful instrument to guide any producer/holder that have oil wastes classified under the code $12.01 .09^{*}$ to manage them on site by applying the principle of treating wastes as close as possible to the generation place avoiding this way the transport of large quantities of liquid hazardous wastes and their associated costs. The benefits of such pretreatment on-site technologies are: on site preventing generation and storage of large volumes of wastes, preserving the depletion of non-renewable natural resources by recovery of valuable oil and water components in the spirit of sustainable development with minimum costs, implementation of circular economy principle stating that wastes from one activity/industry can become raw material substitute for another activity/industry, targeting the "zero" waste approach.

Acknowledgments: This work was realized with the support of Operational Programme Competitiveness 2014-2020, Contract no. 55/05.09.2016, Project ID P_40_300, SMIS 105581, Subsidiary Contract no. 4384/20.03.2019.

\section{References}

1.CAMBIELlA, A., BENITO, J.M., PAZOS, C., COCA, J., Interfacial properties of oil-in water emulsions designed to be used as metalworking fluids, Colloids Surf., A, 305 (1-3), 2007, 112-119.

2. BASEL CONVENTION, Technical Guidelines on used oil re-refining or other re-uses of Previously used oil, 2002, available on line at: http://www.basel.int.

3. KIM, L., MURESAN, A. M., CUCIUREANU, A., GUTA, D., ARAMA, M., CRISTEA, N.I., DEDIU, V., Proceedings of $20^{\text {th }}$ International Symposium "The Environment and the Industry", Bucharest, Romania, 28-29 September 2017, p.142.

4. KIM, L., ARAMA, G. M., CUCIUREANU, A., GUTA, D., Handling specific issues of waste hazardousness evaluation according to waste type, Environ. Eng. Manag. J., 17 (12), 2018, 2945-2956. 5. KIM, L., STANESCU, B., CUCIUREANU, A., ARAMA, M.G., TRAISTARU, G.A., Proceedings of 18th International Multidisciplinary Scientific Geo Conference, Conference Proceedings Energy and Clean Technologies, Recycling, Air Pollution and Climate Change, Albena, Bulgaria, 27 June 06 July 2018, 18(4.2), p. 121.

6. KIM, L., ARAMA, G.M., Ecological risk prediction in relation to the potential detrimental consequences at disposal of different industrial wastes, Environ. Eng. Manag. J., 17(9), 2018, 22012210.

7. GUTA, D., CUCIUREANU, A., KIM, L., ARAMA, M., Proceedings of $20^{\text {th }}$ International Symposium "The Environment and the Industry", Bucharest, Romania, 28-29 September 2017, p.289.

8. GUTA, D., ARAMA, G.M., STANESCU, B., BATRINESCU, G., LEHR, C.B., Proceedings of International Congress on "Green Infrastructure and Sustainable Societies/Cities" (GreInSus), Izmir, Turkey, 08 - 10 May 2014, p. 82. 
9. MADANHIRE, I., MBOHWA, C., Mitigating Environmental Impact of Petroleum Lubricants, Springer International Publishing Switzerland, E-book 2016, 1-256.

https://doi.org/10.1007/978-3-319-31358-0

10. ASTRUP, T.F., TONINI, D., TURCONI, R., BOLDRIN, A., Life cycle assessment of thermal Waste-to-Energy technologies: Review and recommendations, Waste Manage., 37, 2015, 104-115.

11. KIM, L., STANESCU, B., SERBANESCU, A., CUCIUREANU, A., ARAMA, M., Proceedings of $21^{\text {st }}$ International Symposium "The Environment and the Industry", Bucharest, Romania, 20-21 September 2018, p.63.

12. ARAMA, G. M., KIM, L., CUCIUREANU, A., SERBANESCU, A., NICOLESCU I., BARBU, M., STANESCU, B., TRAISTARU, G., Proceedings of $21^{\text {st }}$ International Symposium "The Environment and the Industry”, Bucharest, Romania, 20-21 September 2018, p.206.

13. SERBANESCU, A., BARBU, M., NICOLESCU, I., ARAMA, G.M., Proceedings of $21^{s t}$ International Symposium "The Environment and the Industry”, Bucharest, Romania, 20-21 September 2018, p.242.

14. KORHONEN, J., HONKASALO, A., SEPPÄLÄ, J., Circular economy as an essentially contested concept, Ecol. Econ.,143, 2018, p.37.

15. KORHONEN, J., NUUR, C., FELDMANN, A., BIRKIE, S.E., Circular economy as an essentially contested concept, J. Clean. Prod., 175, 2018, 544-552.

16. Directive 2008/98/EC of the European Parliament and of the Council of 19 November 2008 on waste and repealing certain Directives, Official Journal of European Communities, L. 312 of 22 November 2008, Brussels.

17. PINTARIC, Z.N., SKOF, G.P., KRAVANJA, Z., Milp synthesis of separation processes for waste oil-in-water emulsions treatment, Chem. Sci. Eng., 10(1), 2016, 120-130.

18. DOSHI, B., REPO, E., HEISKANEN, J.P., SIRVIO, J.A., SILLANAPÄ̈̈, M., Sodium salt of oleoyl carboxymethyl chitosan: A sustainable adsorbent in the oil spill treatment, J. Clean. Prod., 170, 2018, 339-350.

19. MiHAILA, E., MUNTEANU, R., ARAMA, M., CIUCULESCU, R., GHITA, I., Treatment with polymers of waste-waters from food industry, Rev. Roum. Chim., 39 (7), 1994, 851-853.

20. Law no 458/2002 regarding the quality of the potable water, Official Monitor no. 875, Bucharest, 2011.

21. ARAMA, G.M., PASCU, L.F., LEHR, C., Prediction of the concentration of pollutants wave in aquatic environment using rough set theory, Environ. Eng. Manag. J., 16(5), 2017, 1217-1225.

22. BUMBAC, C., DIACU, E., Coupled Chemical and Biological Treatment of Oil Contaminated Soils, Rev. Chim., 63(11), 2012, 1167-1171.

23. BUMBAC, C., MANEA, E.E., TIRON, O., BADESCU, V.R., Correlation Between Wastewater Treatment Performances and Sludge Characteristics, Rev. Chim., 69(1), 2018, 10-13.

24. CUCIUREANU, A., KIM, L., LEHR, C.B., ENE, C., The Groundwater Quality of the Area Tailings Mining Ponds in the North of Romania, Rev. Chim., 68(8), 2017, 1695-1699.

Manuscript received: 21.11.2019 